\title{
Hepatoprotective activity of Mentha arvensis in anti-tubercular drugs induced hepatotoxicity in rats
}

\author{
Sartaj Ahmad Mir ${ }^{1}$, G. Jeyabalan ${ }^{1}$, Gazala Parveen ${ }^{2}$, Mujeeb Ur Rahman ${ }^{1 *}$ \\ ${ }^{1}$ Alwar Pharmacy College, MIA Alwar, Rajasthan, INDIA \\ ${ }^{2}$ Sunrise Pharmacy College, Sunrise University, Alwar, Rajasthan, INDIA
}

\begin{abstract}
Received: 21 April, 2020
Accepted: 19 June, 2020

*Correspondence to:

Dr. Mujeeb Ur Rahman,

Email:
\end{abstract}

mujeebhamdard@gmail.com

Copyright: (C) the author(s), publisher and licensee Indian Academy of Pharmacists. This is an open-access article distributed under the terms of the Creative Commons Attribution NonCommercial License, which permits unrestricted noncommercial use, distribution, and reproduction in any medium, provided the original work is properly cited.

Published by: OZZIE Publishers

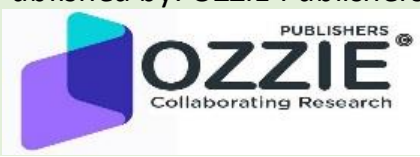

\begin{abstract}
Mentha arvensis L. (Lamiaceae), usually known as Pudina, and traditionally used for various therapeutic purposes like food seasoner, household remedy, and industrial purposes etc. The present study appraised the hepatoprotective activity of the methanol extract of Mentha arvensis L. (MEMA) against by isoniazid and rifampicin (50 mg INH$100 \mathrm{mg}$ RMP) induced liver impairment in rats. The dose of MEMA was 500 and 1000 $\mathrm{mg} / \mathrm{kg}$ daily for 28 days given by orally and Silymarin as a standard drug $(100 \mathrm{mg} / \mathrm{kg})$ was used. On basis of the biochemical estimation of liver function tests (SGPT, SGOT, ALP, total protein and total billirubin), antioxidant assays of liver homogenate (lipid peroxidation, reduced glutathione content, superoxide dismutase and catalase activity) and histological study of liver tissue, the hepatoprotective activity were evaluated. The treated animals, the toxicity of INH were controlled prominently by restoration of the biochemical parameters as well as by the improvement of the antioxidant status as normal values. The results demonstrate that the methanol extract of Mentha arvensis has hepatoprotective activity against INH induced hepatotoxicity in rats.
\end{abstract}

KEYWORDS: Anti-tubercular drugs, hepatoprotective, antioxidant, Silymarin, Mentha arvensis.

\section{INTRODUCTION}

As per the report of World Health Organization (WHO), based on several publishing about codex of 91 countries (pharmacopeia) and medicinal plants may be approximately 20 thousand. Mentha species have essential oil, there are basic constituents such as menthol (33-60\%), menthone (15-32\%), isomenthone (2-8\%), 1.8 sineol (eucalyptols) (5-13\%), menthyl acetate $(2-11 \%)$ menthofuran $(1-7 \%)$, limonene (1$7 \%), \quad \beta$-myrcene $(0.1-1.7 \%), \quad \beta$-caryophyllene $(2-4 \%)$, pulegone $(0.5-1.6 \%)$ carvone $(1 \%)[1]$.

Mentha species have important therapeutic effects such as anti-inflammatory, analgesic, DNA damage protecting activity, antipyretic, anti-androgenic, antioxidant, antimicrobial, cytotoxic, antiviral, antiemetic, antibacterial, antiparazitic, antiallergic, sedative, anti-chlamydial, radioprotection, anti-cholinesterase, antispasmodic, acute toxicity effect, anti-mutagenic, cardiovascular effects and antitumour effects [2-6]. It is reported that plant based therapeutic agents like silymarin from Silybum marianum (milkthistle) are used worldwide as hepatoprotective [7].

Tuberculosis (TB), a disease which is caused by a bacillus (Mycobacterium tuberculosis). TB remains a severe health problem among certain world populations in the developing countries [8]. The most frequent adverse effects of anti-tubercular drugs are skin reactions, hepatitis and gastro-intestinal problèmes [9, 10]. The major deterrent to the prolonged use of both drugs is their potential to cause hepatotoxicity and further increased when the two drugs are used in combination $[11,12]$. On the basis previous research, we have seen that Mentha avrensis proved as potential pharmacological effects in sevral experimental models. However, there are no reported any hepatoprotective effect in isoniazid (INH) and Rifampin (R) induced experimental model of hepatotoxic. Hence, this study is to propose the evaluate the hepatoprotective activity of Mentha arvensis in anti-tubercular drug induced hepatotoxicity in rats.

\section{MATERIALS AND METHODS: \\ Plant materials}

The chemicals used in this research work were analytical grade. The leaves of Mentha arvensis were purchased from local market of Alwar. To remove dirt and soil, the freshly collected leaves of Mentha arvensis were washed with distilled water and dried in shade in a ventilated place at room temperature. 
Preliminary phytochemical screening for presence of different phytoconstituents

The extracts of the plant material were submitted to preliminary phytochemical screening for the detection of various phytochemical constituents.

\section{Extraction $t$ of plant material}

500 gm coarse powdered of airdried leaves of Mentha arvensis loaded down in muslin cloth and submitted to Soxhlet Extractor for continuous Hot extraction with petroleum ether, chloroform, alcohol and distilled water, separately. Then the all extracts were filtered and filtrate was evaporated.

\section{Animal}

Adult Wistar rats (male) weighing $160 \pm 20 \mathrm{~g}$ were procured from the Alwar Pharmacy College, Alwar. For the housing of animals, separate polypropylene cages were acclimatized at a temperature- and humidity-controlled room at an ambient temperature of $25^{\circ} \pm 2{ }^{\circ} \mathrm{C}$ with $12 \mathrm{~h}$ light/dark cycle before and during the experimental instigation. Animals were kept on a standard pellet diet ((Lipton, Calcutta, India) and water ad libitum. Administration of extract was done orally, and that for toxicant was done by intraperitoneal (i.p.) route in the morning session throughout the study period. All investigational proceedings concerned with animals were conducted as per the guidelines of Committee for the Purpose of Control and Supervision on Experiments on Animals (CPCSEA). The study protocol was approved by the Ethical Institutional Animal Ethical Committee.

\section{In vivo study of plant extract}

The rats were randomly distributed into 6 groups, each group containing 5 rats. In this study hepatotoxicity is induced by isoniazid and rifampicin (50 mg INH-100 mg RMP). Drugs treatment was given as per the schedule given below. Isoniazid and rifampicin were administered per oral after the half an hour from administration of test drugs in each group for $28^{\text {th }}$ days and with draw blood from rat tail vein under ether anesthesia for liver function test.

Table A: Experimental Schedule

\begin{tabular}{|l|l|l|}
\hline Groups & Drug Treatment & Dose $(\mathbf{m g} / \mathrm{kg})$ \\
\hline I & Control & CMC $(5 \mathrm{ml} / \mathrm{kg}$ p.o.) once a day for 28th days \\
\hline II & INH+R & $50 \mathrm{mg} / \mathrm{kg}+100 \mathrm{mg} / \mathrm{kg}$ each, p.o daily for 28th days \\
\hline III & Silymarin $(\mathrm{S})+\mathrm{INH}+\mathrm{R}$ & $\begin{array}{l}100 \mathrm{mg} / \mathrm{kg}(\mathrm{S}) \mathrm{p} .0 \text { and } 50 \mathrm{mg} / \mathrm{kg}(\mathrm{INH}+\mathrm{R}) \text { each, p.o. daily } \\
\text { for } 28 \mathrm{th} \text { days }\end{array}$ \\
\hline IV & MA1+INH+R & $\begin{array}{l}500 \mathrm{mg} / \mathrm{kg}(\mathrm{MA} 1) \text { p.o. daily and } 50 \mathrm{mg} / \mathrm{kg}(\mathrm{INH}+\mathrm{R}) \\
\text { each for } 28 \mathrm{th} \text { days }\end{array}$ \\
\hline V & MA2+INH+R & $\begin{array}{l}1000 \mathrm{mg} / \mathrm{kg} \text { p.o daily and } 50 \mathrm{mg} / \mathrm{kg}(\mathrm{INH}+\mathrm{R}) \text { (INH+R) } \\
\text { each for } 28 \mathrm{th} \text { days }\end{array}$ \\
\hline VI & MA2 PERSE & $1000 \mathrm{mg} / \mathrm{kg}$ only test drug p.o daily for 28th days \\
\hline
\end{tabular}

CMC-Carboxy methyl cellulose, INH-Isoniazid, R- Ripampicin, MA2_ Higher dose of Mentha arvensis extract, MA1- Lower dose of Mentha arvensis extract.

\section{Parameters to be assessed}

\section{Liver function test in serum}

\section{Biochemical estimation}

Estimation of SGOT (serum), Estimation of SGPT (serum) [13], Estimation of alkaline phosphatase (serum) [14], Estimation of total bilirubin (serum)[15], Serum was analyzed for the following parameters as aspartate transaminase (AST), alanine transaminase (ALT), alkaline phosphate (ALP) and total billirrubin (TB).

\section{Biochemical estimation (in Liver tissue)}

Thiobarbituric Acid Reactive Substances [16], Glutathione [17], Superoxide Dismutase [18] , Catalase [19], Protein [20]

\section{Statistical analysis}

The statistical data was executed by using GRAPHPAD INSTAT 3 software (Graph Pad Software Inc, San Diego,
CA). Results got from experiments were expressed as arithmetic mean \pm SEM. The comparison between all groups was performed by one-way analysis of variance (ANOVA), and the effects in treatment groups were compared with toxic control or control group by the Dunnet multiple comparison test. $\mathrm{p}<0.05$ was considered to be significant $[* \mathrm{p}<0.05$; $* *<50.01]$.

\section{RESULTS:}

\section{Phytochemical screening}

Phytochemical screening (Table-1) of the extract showed small quantities of alkaloids, saponins, flavonoids and large amounts of cardiac glycosides, triterpenoids, phenolic compounds and tannins.

Table 1: Preliminary phytochemical evaluation of the leaves of Mentha arvensis

\begin{tabular}{|l|l|l|l|l|}
\hline Test for & Pet. Ether Extract & Chloroform Extract & Methanol Extract & Water Extract \\
\hline Alkaloid & - & - & + & + \\
\hline Carbohydrate & - & - & + & + \\
\hline Glycoside & - & - & + & + \\
\hline Phytosterols & + & + & - & + \\
\hline Fixed oils and fats & + & + & - & - \\
\hline Saponins & - & - & + & + \\
\hline Flavonoids & - & - & - & + \\
\hline
\end{tabular}




\begin{tabular}{|l|l|l|l|l|}
\hline $\begin{array}{l}\text { Proteins and amino } \\
\text { acids }\end{array}$ & - & - & + & - \\
\hline Gum and Mucilage & - & - & - & - \\
\hline Phenolic Compounds & - & - & - & - \\
\hline Volatile oils & - & - & - & - \\
\hline
\end{tabular}

Present (+); Absent (-)

Table 2: Effect of Mentha arvensis on TBAR and Antioxidant enzymes

\begin{tabular}{|c|c|c|c|c|c|}
\hline Group & Drug treatment & $\begin{array}{c}\text { TBARs } \\
\text { (nmoles MDA/ mg } \\
\text { protein }\end{array}$ & $\begin{array}{c}\text { GSH } \\
(\mu \mathrm{g} / \mathrm{mg} \text { protein) }\end{array}$ & $\begin{array}{c}\text { SOD } \\
\text { (units/mg protein) }\end{array}$ & $\begin{array}{c}\text { CATALASE } \\
\left(\mathrm{nmol} \text { of } \mathrm{H}_{2} \mathrm{O}_{2} / \mathrm{mg}^{2}\right. \\
\text { protein) }\end{array}$ \\
\hline I & Control & $0.314 \pm 0.021$ & $3.019 \pm 0.237$ & $2.349 \pm 0.317$ & $4.45 \pm 0.763$ \\
\hline II & INH+R & $1.917 \pm 0.051 \# \#$ & $0.798 \pm 0.156 \# \#$ & $0.701 \pm 0.217 \# \#$ & $1.32 \pm 0.288 \# \#$ \\
\hline III & Silymarin(S)+INH+R & $0.413 \pm 0.038^{* *}$ & $2.831 \pm 0.309 * *$ & $2.042 \pm 0.401 * *$ & $4.21 \pm 0.892^{* *}$ \\
\hline IV & MA1+INH+R & $0.719 \pm 0.012^{*}$ & $1.452 \pm 0.312^{*}$ & $1.071 \pm 0.211$ & $3.069 \pm 0.921$ \\
\hline V & MA2+INH+R & $0.39 \pm 0.081 * *$ & $2.621 \pm 0.287 * *$ & $2.008 \pm 0.097 * *$ & $4.031 \pm 1.321 * *$ \\
\hline VI & MA2 PERSE & $0.348 \pm 0.078$ & $2.881 \pm 0.213$ & $2.412 \pm 0.305$ & $4.37 \pm 1.932$ \\
\hline
\end{tabular}

Result are expressed as MEAN \pm SEM, \#\# $\mathbf{P}<0.01$; Toxic control group Vs Normal control group, $* * \mathbf{P}<0.01$; Treated group Vs Toxic control group, ${ }^{*} \mathbf{P}<0.05$; Treated group Vs Toxic control group

Table 3: Effects of Mentha arvensis on liver profile

\begin{tabular}{|c|c|c|c|c|c|c|}
\hline & & & & & & \\
\hline Group & $\begin{array}{c}\text { Drug } \\
\text { Treatment }\end{array}$ & SGOT (IU/L) & $\begin{array}{l}\text { SGPT } \\
(\text { IU/L) }\end{array}$ & $\begin{array}{c}\mathbf{A L P} \\
(\mathbf{I U} / \mathbf{L})\end{array}$ & $\begin{array}{c}\text { TOTAL } \\
\text { BILIRUBIN } \\
(\mathbf{m g} / 100 m l)\end{array}$ & $\begin{array}{c}\text { TOTAL } \\
\text { PROTEIN } \\
\text { (mg/dl) }\end{array}$ \\
\hline I & Control & $45.73 \pm 7.342$ & $21.42 \pm 3.146$ & $11.543 \pm 1.243$ & $1.76 \pm 0.762$ & $9.762 \pm 2.617$ \\
\hline II & $\mathrm{INH}+\mathrm{R}$ & $\begin{array}{l}108.52 \pm 6.31 \# \\
\#\end{array}$ & $\begin{array}{l}75.03 \pm 2.072 \# \\
\#\end{array}$ & $\begin{array}{l}57.782 \pm 3.671 \# \\
\#\end{array}$ & $4.21 \pm 0.971 \# \#$ & $4.431 \pm 1.421 \# \#$ \\
\hline III & $\begin{array}{l}\text { Silymarin } \\
(\mathrm{S})+\mathrm{INH}+\mathrm{R}\end{array}$ & $59.04 \pm 6.31 * *$ & $\begin{array}{l}38.29 \pm 1.873 * \\
*\end{array}$ & $\begin{array}{l}13.419 \pm 0.987 * \\
*\end{array}$ & $1.91 \pm 0.432 * *$ & $8.761 \pm 2.108 * *$ \\
\hline IV & $\mathrm{MA} 1+\mathrm{INH}+\mathrm{R}$ & $88.77 \pm 9.12 *$ & $52.5 \pm 4.756 *$ & $36.672 \pm 1.21$ & $2.98 \pm 0.512 *$ & $5.672 \pm 1.091$ \\
\hline V & MA2+INH+R & $62.32 \pm 2.11^{* *}$ & $\begin{array}{c}35.61 \pm 3.315^{*} \\
*\end{array}$ & $14.781 \pm 1.671 *$ & $2.22 \pm 0.871 * *$ & $8.001 \pm 2.812 * *$ \\
\hline VI & MA2 PERSE & $49.58 \pm 9.004$ & $25.32 \pm 2.182$ & $12.415 \pm 2.098$ & $1.87 \pm 0.671$ & $9.01 \pm 1.918$ \\
\hline
\end{tabular}

Result were expressed as MEAN \pm SEM, \#\# $\mathbf{P}<0.01$; Toxic control group Vs Normal control group, $* * \mathbf{P}<0.01$; Treated group Vs Toxic control group, * $\mathbf{P}<0.05$; Treated group Vs Toxic control group

\section{Effect of Mentha arvensis of TBARS in liver tissue}

The treated Group with INH+R exhibited significant $(P<0.01)$ enhance in the levels of TBARS in the liver tissue compared to group treated with Normal Saline. Pre-treatment with MIA2 in INH+R -induced rats significantly $(P<0.01)$ reduced the levels of TBARS in the liver tissue as compared to group treated with $\mathrm{INH}+\mathrm{R}$. Pre-treatment with Silymarin in INH+R -induced rats significantly $(P<0.01)$ decreased the levels of TBARS in the liver tissue as compared to group treated with $\mathrm{INH}+\mathrm{R}$. Pre-treatment with MIA1 in $\mathrm{INH}+\mathrm{R}$-induced rats significantly $(P<0.05)$ reduced the levels of TBARS in the liver tissue as compared to group treated with INH+R.
Pre-treatment with only MIA2 rats non-significantly $(P>0.05)$ decreased the levels of TBARS in the liver tissue as compared to group treated with normal saline (Table 2).

\section{Effect of Mentha arvensis of SOD in liver tissue}

Group treated with $\mathrm{INH}+\mathrm{R}$ exhibited significant $(P<0.01)$ reduce in the levels of SOD in the liver tissue compared to group treated with Normal Saline. Pre-treatment with MIA2 in $\mathrm{INH}+\mathrm{R}$-induced rats significantly $(P<0.01)$ enhanced the levels of SOD in the liver tissue as compared to group treated with $\mathrm{INH}+\mathrm{R}$. Pre-treatment with Silymarin in $\mathrm{INH}+\mathrm{R}$ induced rats significantly $(P<0.01)$ increased the levels of $\mathrm{SOD}$ in the liver tissue as compared to group treated with $\mathrm{INH}+\mathrm{R}$. Pre-treatment with MIA1 in $\mathrm{INH}+\mathrm{R}$-induced rats 
nonsignificantly $(P>0.05)$ increased the levels of SOD in the liver tissue as compared to group treated with INH+R. Pretreatment with only MIA2 rats nonsignificantly $(P>0.05)$ increased the levels of SOD in the liver tissue as compared to group treated with normal saline(Table 2).

\section{Effect of Mentha arvensis of GSH in liver tissue}

Group treated with $\mathrm{INH}+\mathrm{R}$ exhibited significant $(P<0.01)$ reduce in the levels of GSH in the liver tissue compared to group treated with Normal Saline. Pre-treatment with MIA2 in $\mathrm{INH}+\mathrm{R}$-induced rats significantly $(P<0.01)$ enhanced the levels of GSH in the liver tissue as compared to group treated with $\mathrm{INH}+\mathrm{R}$. Pre-treatment with Silymarin in $\mathrm{INH}+\mathrm{R}$ induced rats significantly $(P<0.01)$ enhanced the levels of GSH in the liver tissue as compared to group treated with $\mathrm{INH}+\mathrm{R}$. Pre-treatment with MIA1 in $\mathrm{INH}+\mathrm{R}$-induced rats significantly $(P<0.05)$ increased the levels of GSH in the liver tissue as compared to group treated with INH+R. Pretreatment with only MIA2 rats nonsignificantly $(P>0.05)$ changed the levels of GSH in the liver tissue as compared to group treated with normal saline(Table 2).

\section{Effect of Mentha arvensis of CATALASE in liver tissue}

Group treated with $\mathrm{INH}+\mathrm{R}$ exhibited significant $(P<0.01)$ reduce in the levels of CATALASE in the liver tissue compared to group treated with Normal Saline. Pre-treatment with MIA2 in INH+R -induced rats significantly $(P<0.01)$ enhanced the levels of CATALASE in the liver tissue as compared to group treated with INH+R. Pre-treatment with Silymarin in $\mathrm{INH}+\mathrm{R}$-induced rats significantly $(P<0.01)$ increased the levels of CATALASE in the liver tissue as compared to group treated with INH+R. Pre-treatment with MIA1 in INH+R -induced rats nonsignificantly $(P>0.05)$ increased the levels of CATALASE in the liver tissue as compared to group treated with INH+R. Pre-treatment with only MIA2 rats nonsignificantly $(P>0.05)$ enhanced the levels of CATALSE in the liver tissue as compared to group treated with normal saline(Table 2).

\section{Effect of Mentha arvensis of SGOT in Serum}

Group treated with $\mathrm{INH}+\mathrm{R}$ exhibited significant $(P<0.01)$ enhance in the levels of SGOT compared to group treated with Normal Saline. Pre-treatment with MIA2 in INH $+\mathrm{R}$-induced rats significantly $(P<0.01)$ reduced the levels of SGOT in serum as compared to group treated with INH+R. Pretreatment with Silymarin in INH+R -induced rats significantly $(P<0.01)$ reduced the levels of SGOT in serum as compared to group treated with $\mathrm{INH}+\mathrm{R}$. Pre-treatment with MIA1 in $\mathrm{INH}+\mathrm{R}$-induced rats significantly $(P<0.05)$ reduced the levels of SGOT in serum as compared to group treated with INH+R. Pre-treatment with only MIA2 rats nonsignificantly $(P>0.05)$ reduced the levels of SGOT in serum as compared to group treated with normal saline(Table 3 ).

\section{Effect of Mentha arvensis of SGPT in Serum}

Group treated with $\mathrm{INH}+\mathrm{R}$ exhibited significant $(P<0.01)$ enhance in the levels of SGPT compared to group treated with Normal Saline. Pre-treatment with MIA2 in INH+R -induced rats significantly $(P<0.01)$ reduced the levels of SGPT in serum as compared to group treated with INH+R. Pretreatment with Silymarin in $\mathrm{INH}+\mathrm{R}$-induced rats significantly $(P<0.01)$ reduced the levels of SGPT in serum as compared to group treated with $\mathrm{INH}+\mathrm{R}$. Pre-treatment with MIA1 in $\mathrm{INH}+\mathrm{R}$-induced rats significantly $(P<0.05)$ reduced the levels of SGPT in serum as compared to group treated with INH+R. Pre-treatment with only MIA2 rats nonsignificantly $(P>0.05)$ changed the levels of SGPT in serum as compared to group treated with normal saline(Table 3 ).

\section{Effect of Mentha arvensis of ALP in Serum}

Group treated with $\mathrm{INH}+\mathrm{R}$ exhibited significant $(P<0.01)$ enhance in the levels of ALP compared to group treated with Normal Saline. Pre-treatment with MIA2 in INH $+\mathrm{R}$-induced rats significantly $(P<0.01)$ reduced the levels of ALP in serum as compared to group treated with $\mathrm{INH}+\mathrm{R}$. Pre-treatment with Silymarin in INH+R -induced rats significantly $(P<0.01)$ reduced the levels of ALP in serum as compared to group treated with INH+R. Pre-treatment with MIA1 in INH+R induced rats nonsignificantly $(P>0.05)$ reduced the levels of ALP in serum as compared to group treated with INH+R. Pretreatment with only MIA2 rats nonsignificantly $(P>0.05)$ changed the levels of ALP in serum as compared to group treated with normal saline(Table 3).

\section{Effect of Mentha arvensis of Total Bilirubin in Serum}

Group treated with $\mathrm{INH}+\mathrm{R}$ exhibited significant $(P<0.01)$ enhance in the levels of total bilirubin compared to group treated with Normal Saline. Pre-treatment with MIA2 in $\mathrm{INH}+\mathrm{R}$-induced rats significantly $(P<0.01)$ reduced the levels of total bilirubin in serum as compared to group treated with $\mathrm{INH}+\mathrm{R}$. Pre-treatment with Silymarin in $\mathrm{INH}+\mathrm{R}$-induced rats significantly $(P<0.01)$ reduced the levels of total bilirubin in serum as compared to group treated with INH+R.

Pre-treatment with MIA1 in INH+R -induced rats significantly $(P<0.05)$ reduced the levels of total bilirubin in serum as compared to group treated with INH+R. Pre-treatment with only MIA2 rats nonsignificantly $(P>0.05)$ changed the levels of total bilirubin in serum as compared to group treated with normal saline(Table 3 ).

\section{Effect of Mentha arvensis of Total protein in Serum}

Group treated with $\mathrm{INH}+\mathrm{R}$ exhibited significant $(P<0.01)$ enhance in the levels of total protein compared to group treated with Normal Saline. Pre-treatment with MIA2 in INH+R induced rats significantly $(P<0.01)$ reduced the levels of total protein in serum as compared to group treated with INH+R. Pre-treatment with Silymarin in $\mathrm{INH}+\mathrm{R}$-induced rats significantly $(P<0.01)$ reduced the levels of total protein in serum as compared to group treated with INH+R. Pretreatment with MIA1 in INH $+\mathrm{R}$-induced rats nonsignificantly $(P>0.05)$ reduced the levels of total protein in serum as compared to group treated with INH+R. Pre-treatment with only MIA2 rats nonsignificantly $(P>0.05)$ changed the levels of total protein in serum as compared group treated with normal saline(Table 3).

\section{DISCUSSION}

Tuberculosis still a serious health problem among certain world populations in the developing countries [8]. With the coming of anti-tubercular agents, there has been a graded improvement in the history of the disease. Among the antitubercular agents, isoniazid (INH) and rifampin (RMP) are the first-line agents and a backbone of combination therapy along with second-line drugs, pyrazinamide, ethambutol and streptomycin. Anti-tubercular agents- inducted hepatotoxicity causes significant morbidity and mortality. The major deterrent to the prolonged use of both drugs is their possible to cause hepatotoxicity and further increased when the two drugs 
are used in combination [11, 12]. The past studies have proposed a possible role of enhanced formation of toxic INH metabolites (acetylisoniazid, acetylhydrazine, hydrazine and their reactive products) by RMP and the resultant oxidative injury in the hepatotoxicity caused by combination drugs [13].

Figure 1: Histopathology of liver from control and experimental groups of animals, circle mark indicated that damage of liver cell. (a) Liver section of normal control Group I, (b) liver incision of antitubercular drug (INH+R)-treated Group II, (c) liver section of $(\mathrm{INH}+\mathrm{R})$ and Mentha arvensis extract $(500 \mathrm{mg} / \mathrm{kg}$ )-treated Group IV, (d) liver section of (INH+R) and Mentha arvensis extract $(1000 \mathrm{mg} / \mathrm{kg})$ treated Group V, and (e) liver section of rats treated (INH+R)- 50mg and $100 \mathrm{mg} / \mathrm{kg}$ of silymarin Group III

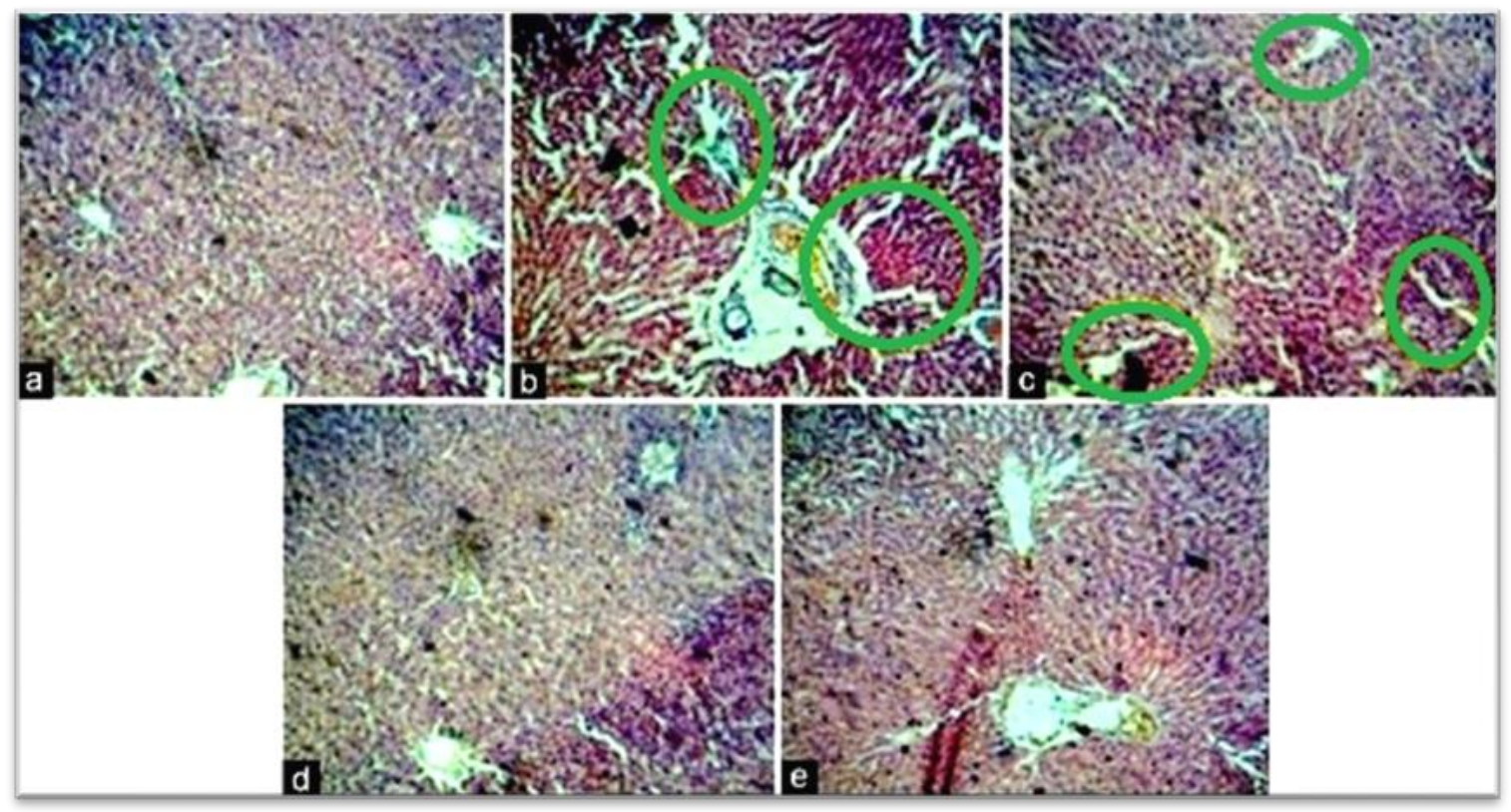

The efforts have been built in the past to investigate the hepatoprotective agents of some herbal preparations, synthetic compounds or natural antioxidants against the toxicity of these drugs. Silymarin, an extract from the seeds of $S$. marianum, has been shown to protect rat liver against toxic effects of antitubercular drugs [7]. It has reported that Mentha arvensis Linn. has been used as antiseptic, carminative, headache, stomachic, and a refrigerant. Theraputically, this plant has been proved to be useful in various conditions: Anti-ulcerogenic Effect, inflammatory bowel syndrome. However, there is no data is available on the effectiveness of Mentha arvensis in the liver diseases and in particular hepatic injury induced by antitubercular drugs. The present study is designed to evaluate the hepatoprotective and antioxidant potential of Mentha arvensis against liver injury caused by INH and RMP combination in rats in order to understand the mechanism of hepatoprotective activity of Mentha arvensis.

Our study hepatotoxicity was induced in rats by intraperitoneal administration of anti-tubercular drugs combination of INH and $\mathrm{R}$. The stage of liver injury was apparent from about two fold increase in serum marker enzymes, which was in line with the observations reported in previous studies where this model has been used to clarify the mechanism of hepatotoxicity produced by anti-tubercular drugs. Various mechanisms have been used to explain the toxicity of these drugs. Recent studies have advised that the toxic metabolites of INH, mainly CYP 2E1-mediated reactive oxidative products of hydrazine and acetylhydrazine, play a essential role in liver injury. The use of INH and R in combination leads to enhance the risk of hepatotoxicity in both clinical and experimental studies. Rifampin alone may also raise hepatocellular dysfunction. But earlier its mechanism of hepatotoxicity was unknown. Later on, it was described that rifampin particularly, activates cytochrome P450 (CYP3A4) via hepatocyte xeno sensing pregnane $\mathrm{X}$ receptor (PXR) which leads to increased metabolism of isoniazid and thus formation of toxic metabolites. Rifampin, a potent inducer of xenobiotic metabolising enzymes and increase the metabolism of isoniazid by a hydrolase and CYP 2E1 to reactive toxic metabolites. Pretreated with the extract of Mentha arevesis protect the liver tissue by significant reducing the liver markers enzyme in the serum.

Pre-administration of $M$. Arvensis with (INH-R) combination in our research resulted in marked protection against the INH$\mathrm{R}$ induced hepatotoxicity. This was further supported by restoration of liver marker enzymes by $M$ Arvensis treatment. Moreover, the ethanol extract of Mentha arvensis Linn. reported as hepatoprotective and antioxidant activity against carbon tetrachloride induced hepatic damage in rats. In fact, Pre-administration of $M$. Arvensis with (INH-R) combination preserved the hepatocytes cell by restoring antioxidant activity and liver marker enzymes.

\section{CONCLUSION:}

On the basis of results, The results of the our histopathological study (Figure 8) suggest that the fundamental mechanisms of hepatoprotective action of Mentha Avrensis and its phytochemical constitutes regard suppression of oxidative stress, reinforcement of cellular antioxidant defenses, along with restoration of liver cell membrane stabilization by reducing liver marker enzymes in INH- $\mathrm{R}$ induced hepatotoxicity. Mentha Avrensis may be used as a hepatoprotective herbal drug, especially in the patients receiving anti-tubercular therapy which are at a risk of 
hepatotoxicity. Still further research may be expressed out with multiple doses of Mentha Avrensis in various experimental models of hepatotoxicity with a longer duration to confirm our hypothesis.

\section{REFERENCES:}

1. Ameen N, Shafi S. Phramcognostical review on Mentha arvesis L. Int J Cur Res. 2016; 8:34120-34123.

2. Biswas NN, Subarna Saha, Mohammed Khadem Ali. Antioxidant, Antimicrobial, Anticytotic and Analgesic activity of ethanolic extract of Mentha arvensis L. Asia Pac J Trop Biomed. 2014;4(10):792-797.

3. Shah MS, Omer M, Faruk S. Invitro thrombolytic and Cytotoxic evaluation of Mentha arvensis. IOSR J Phar and biolo scie. 2014; 9(5):97-102.

4. Verma S.M, Arora H. Anti-inflammatory and Sedative and Hypnotic activity of the leaves of Mentha arvensis. Annual sci of Life, 2003;23(2): 412-417.

5. Vikas S, Shabir H. Invitro anticancer activity of extracts of Mentha species against Human cancer cells. Ind J Biochem Biophy. 2014;51:416-419.

6. Kowti rajash AHM, Vishwanath $S$, Shivakumar S, Inamdar, Vedamurthy J, Abdul NK. Hepatoprotective and antioxidant activity of ethanol extract of Mentha arvensis leaves against carbon tetrachloride induced hepatic damage in rats. Inter J Pharma Tech Res. 2013; 5(2): 426430.

7. Fraschini F, Demartini G, Esposti, D. Pharmacology of Silymarin. Clin Drug Inven, 2002; 22: 51- 65.

8. World Health Organization Global Tuberculosis Report 2015, World Health Organization, 2015.

9. Gilman AG, Rall TW, Nies AS, Taylor P. Rifamycins: rifampin rifapentine, and rifabutin anti-Mycobacterial drugs, in: L.L. Brunton (Ed.), Chemotherapy of Tuberculosis, Mycobacterium Avium Complex Disease, and Leprosy, Goodman and Gilmans' The Pharmacological Basis of Therapeutics, McGraw-Hill, New York, 2011,1549-1570.

10. D. Yee, C. Valiquette, M. Pelletier, I. Parisien, I. Rocher, D. Menzies, Incidence of serious side effects from first-line
Acknowledgement: None

Conflict of interest: None

Abbreviations used: None

antituberculosis drugs among patients treated for active tuberculosis. Am J Respir Crit Care Med. 2003;167:14721477.

11. Saad EI, El-Gowilly SM, Sherhaa MO, Bistawroos AE. Role of oxidative stress and nitric oxide in the protective effects of a-lipoic acid and aminoguanidine against isoniazid-rifampicin-induced hepatotoxicity in rats, Food Chem Toxicol. 2010;48:1869-1875.

12. Pandit A, Sachdeva T, Bafna P. Drug-induced Hepatotoxicity: A Review. J App Pharm Sci.2012; 02:233243.

13. King J. The hydrolases-acid and alkaline phosphatases' In: Practical Clinical Enzymology, London: Nostrand Company Limited. 1965;191-208.

14. Dangerfield WG, Finlayson R, Estimation of bilirubin in serum. J Clin Pathol.1958; 6: 173.

15. Webster D. Interaction of bromocresol green with isolated serum globulin fractions. Clinica Chimica Acta, 1974;53:109-115.

16. Okhawa H, Ohishi N, Yagi K. Assay for lipid peroxides in animal tissues by thiobarbituric acid reaction. Anal. Biochem.1970;34:30-38.

17. Sedlak, J. Lindsay RH, Estimation of total, protein bound, and nonprotein sulfhydryl groups in tissue with Ellman's reagent. Anal Biochem.1968;25:192-205.

18. Marklund S, Marklund G. Involvement of superoxide anion radical in auto oxidation by pyrogallol and a convenient assay of superoxide dismutase. Eur J Biochem.1974;47:469-474.

19. Claiborne, A., 1985. Catalase activity. In: Greenwald R.A., (Ed.) Handbook of Methods for Oxygen Free Radical Research, CRC Press, Boca Raton, FL. 283-284.

20. Lowry OH, Rosebrough NH, Farr AL, Randall RJ, Protein measurements with the Folin Phenol Reagent. J Biol Chem.1951;193:265-75. 